«Системні технології» 5 (130) 2020 «System technologies»

DOI 10.34185/1562-9945-5-130-2020-02

УДК 519.71

І.В. Колосов, О.В. Поливода, Г.В. Рудакова

\title{
ІДЕНТИФІКАЦІЯ НАПРУЖЕНОГО СТАНУ ЛЮДИНИ-ОПЕРАТОРА
}

Анотація: В статті розглядається можливість ідентифікації напруженого стану людини шляхом визначення параметрів математичної моделі, яка отримується на основі аналізу біофізичних показників, що фіксуються за результатами вимірів. Приведено приклад розрахунку.

Ключові слова: аналіз даних, ідентифікація стану, метод найменших квадратів, оцінка параметрів, динамічний об'єкт, рівень напруженості, спостереження, вимірювання.

Постановка проблеми. При виконанні своїх професійних обов’язків людина доволі часто опиняється в ситуації коли потрібно приймати рішення. В цьому випадку напруженість стану оператора зазвичай підвищується при керуванні будь-яким процесом в реальному чаci, особливо в умовах дефіциту часу. Постійний моніторинг рівня напруженості стану людини дозволяє своєчасно виявити передстресові та стресові стани і вжити певні заходи щодо стабілізації ситуації.

Стан людини може бути визначений за біофізичними параметрами, які змінюються під час виконання операцій різного характеру та можуть вимірюватися за допомогою датчиків [1]. На основі аналізу даних, що фіксуються за результатами вимірів, можна виявити рівень напруженості стану людини та оцінити складність оперативної ситуації. Виникає задача побудови математичної моделі, на основі якої можна адекватно ідентифікувати стан людини-оператора.

Аналіз останніх досліджень і публікацій. Людина-оператор $\epsilon$ динамічною системою, тобто його поведінку можна описати за допомогою системи диференційних рівнянь. В зв’язку з тим, що людина як динамічна система 3 точки зору системного підходу відноситься до класу не повністю керованих та не повністю спостережуваних систем, для іï дослідження доцільно використовувати математичну модель в просторі

(C) Колосов І.В., Поливода О.В., Рудакова Г.В., 2020 
«Системні технологіï» 5 (130) 2020 «System technologies»

станів [2]. Рівняння стану людини-оператора в просторі станів задаються наступним чином

$$
\dot{\mathbf{x}}(t)=\mathbf{A x}(t)+\mathbf{B v}(t),
$$

де $\mathbf{x}(t)$ - вектор біофізичних параметрів людини, які реєструються певною вимірювальною підсистемою; $\mathbf{v}(t)$ - вектор вхідних обурень; $\mathbf{A}$ матриця стану об’єкта; В - матриця впливу вхідних сигналів на зміни стану об’єкта.

Біофізичні параметри суттєво змінюються в залежності від зовнішніх обставин, тому визначення ступеня напруженості стану людини можна здійснювати шляхом ідентифікації параметрів моделі (1) та подальшому аналізі значень компонент матриці стану А.

Для ідентифікації параметрів моделі (1) в реальному часі, доцільно використовувати повторювані процедури, які дозволяють отримати оцінку параметрів моделі при надходженні нових вимірювань [3]. Найбільш відомими повторюваними процедурами є метод стохастичної апроксимації і метод найменших квадратів. Однак, точність методу стохастичної апроксимації досягається при досить великій кількості ітерацій, тому використовувати його при знаходженні параметрів моделі для вирішення задач ідентифікації динамічного об'єкта в реальному часі не варто $[3,4]$.

Мета досліджень. Метою статті є проведення оцінювання параметрів математичної моделі на основі аналізу біофізичних параметрів людини, що реєструються, та обгрунтування доцільності їхнього застосування для ідентифікації напруженого стану.

Викладення основного матеріалу досліджень. Комплекс біофізичних параметрів людини, що реєструються синхронно, відноситься до класу багатомірних часових рядів, для опису яких зазвичай використовують дискретизовану форму рівняння (1), а саме

$$
\mathbf{x}(k+1)=\mathbf{A} \mathbf{x}(k)+\mathbf{b} \mathbf{v}(k) .
$$

Для оцінювання параметрів моделі (2) при наявності достатньо великої вибірки спостережень використаємо наступні вирази [5] 
«Системні технології» 5 (130) 2020 «System technologies»

$$
\begin{aligned}
& \hat{\mathbf{A}}_{n}=\left[\sum_{i=2}^{n} \mathbf{x}(n+2-i) \mathbf{x}^{T}(n+1-i)\right] \cdot\left[\sum_{i=2}^{n} \mathbf{x}(n+1-i) \mathbf{x}^{T}(n+1-i)\right]^{-1} ; \\
& \hat{\mathbf{b}}^{2}=\frac{1}{p(n-1)} \operatorname{tr}\left[\sum_{i=2}^{n} \mathbf{x}(n+1-i) \mathbf{x}^{T}(n+1-i)-\hat{\mathbf{A}}_{n} \sum_{i=2}^{n} \mathbf{x}(n+1-i) \mathbf{x}^{T}(n+2-i)\right],
\end{aligned}
$$

де $n$ - кількість вимірів; $p$ - порядок моделі (розмірність вектору $\mathbf{x}(k)$ ).

Обчислення оцінок параметрів моделі здійснено для трьох динамічних процесів, що характерні для людини: $x_{1}(k)$ - кардіограма, $x_{2}(k)$ реограма, $x_{3}(k)$ - пневмограма. Довжина вибірки даних $N=200$ точок, що фіксувалися на протязі 4 с. Данні спостережень було отримано для двох випадків: 1) - при спокійному (фоновому) стані людини та 2) - при напруженому (стресовому) стані тієї ж особи. В результаті розрахунків отримано оцінки матриці $\hat{\mathbf{A}}_{n}$ та параметра $\hat{\mathbf{b}}$ на основі вибірки довжиною $n=50$ точок.

1) Для фонового стану:

$$
\hat{\mathbf{A}}_{f_{50}}=\left(\begin{array}{ccc}
0.510 & 0.166 & 0.192 \\
0.056 & 0.858 & 0.075 \\
-0.024 & -0.018 & 1.023
\end{array}\right) \text {, }
$$

вектор власних значень матриці $\hat{\mathbf{A}}_{f_{50}}$ одержано у наступному вигляді:

$$
\lambda_{f}=\left(\begin{array}{lll}
0.491 & 0.909 & 0.991
\end{array}\right)^{T}
$$

оцінка коефіцієнту впливу зовнішніх обурень $\hat{b}_{f}=0.1$.

2) Для стресового стану:

$$
\hat{\mathbf{A}}_{s 50}=\left(\begin{array}{ccc}
0.396 & -0.092 & 0.531 \\
0.24 & 0.9 & -0.152 \\
0.039 & 0.0009 & 0.968
\end{array}\right) \text {, }
$$

вектор власних значень матриці $\hat{\mathbf{A}}_{s 50}$ має вигляд

$$
\lambda_{s}=\left(\begin{array}{lll}
0.405 & 1.001 & 0.858
\end{array}\right)^{T},
$$

оцінка коефіцієнту впливу зовнішніх обурень $\hat{b}_{s}=0.088$.

Експериментальні залежності та отримані за моделлю для фонового стану наведені на рис. 1. На рис. 2 показано відносну похибку. 
«Системні технології» 5 (130) 2020 «System technologies»

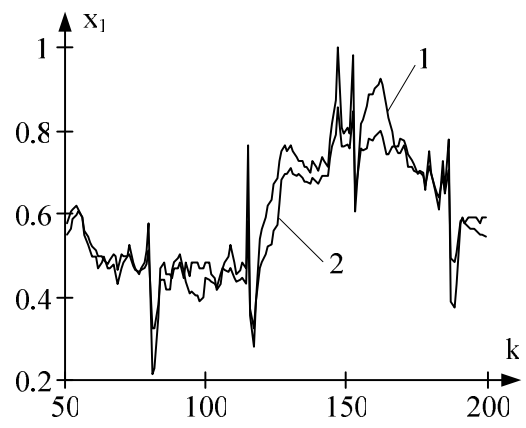

a)
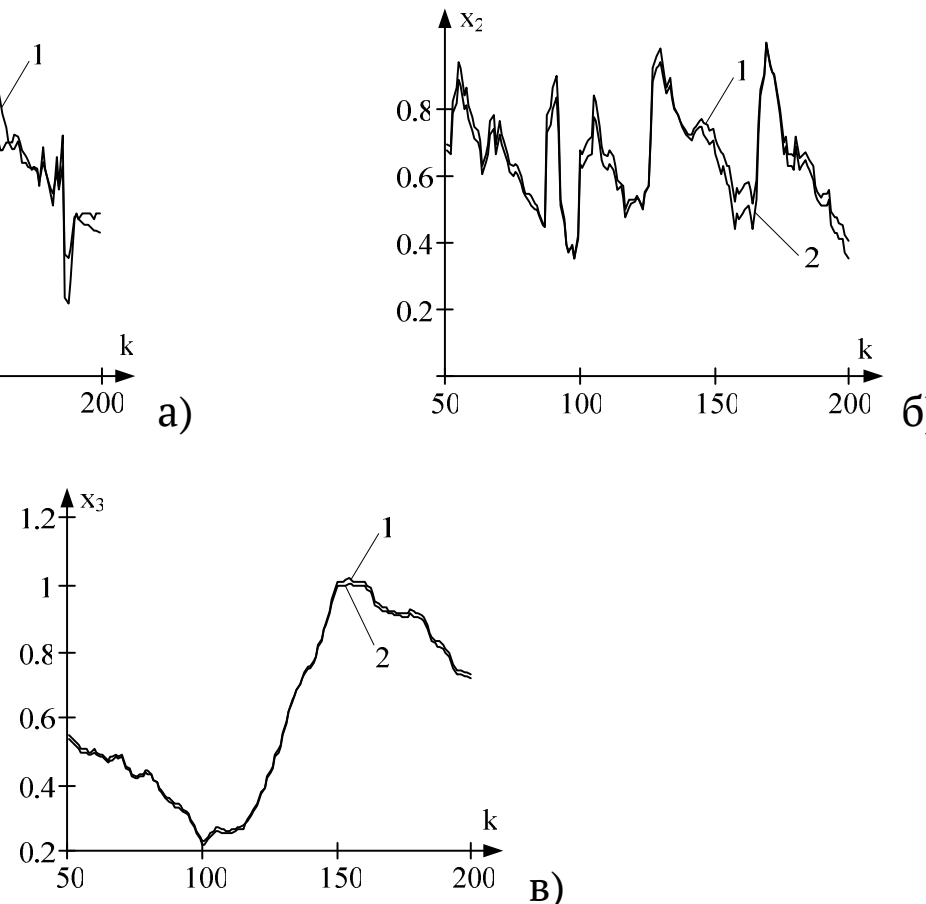

B)

Рисунок 1 - Експериментальні та отримані за моделлю залежності для фонового стану



a)

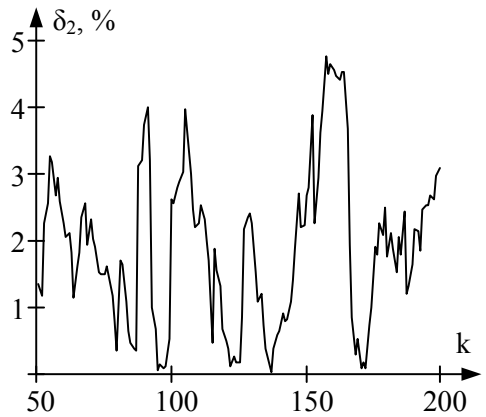

б)

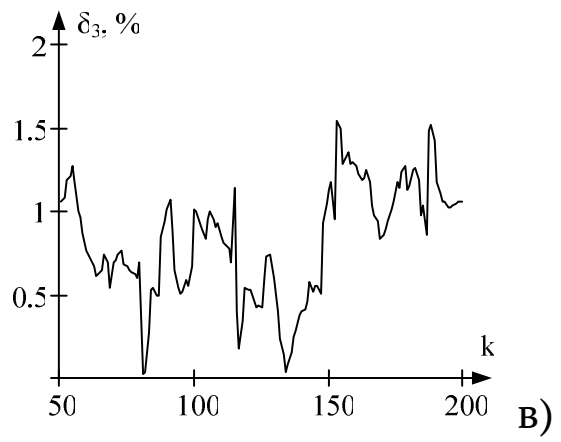

Рисунок 2 - Похибки моделі для фонового стану 
«Системні технології» 5 (130) 2020 «System technologies»

Експериментальні залежності та отримані за моделлю для стресового стану наведені на рис. 3. На рис. 4 показано відносну похибку.
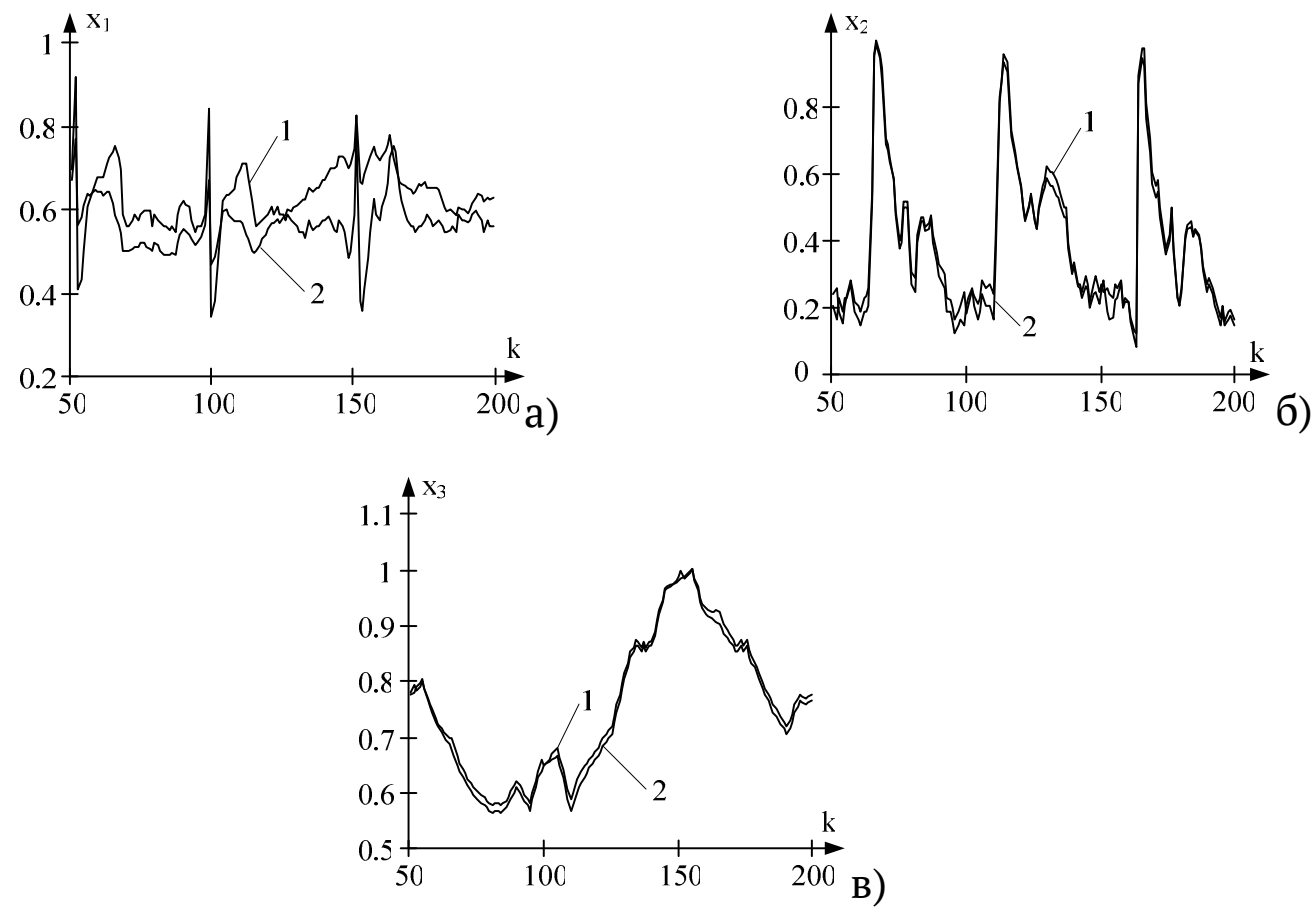

Рисунок 3 - Експериментальні та отримані за моделлю залежності для стресового стану

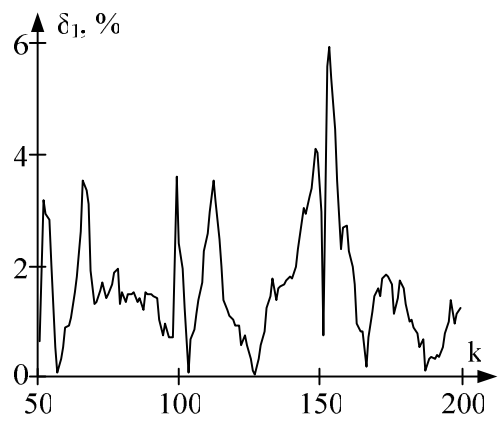

a)

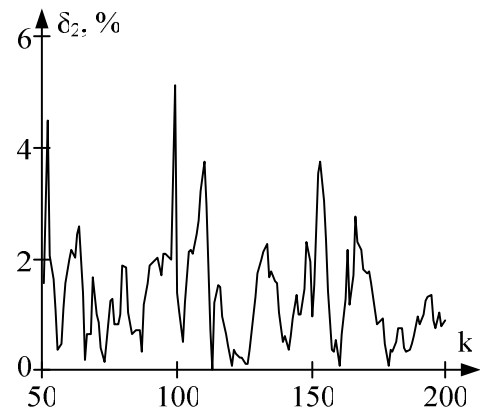

б)

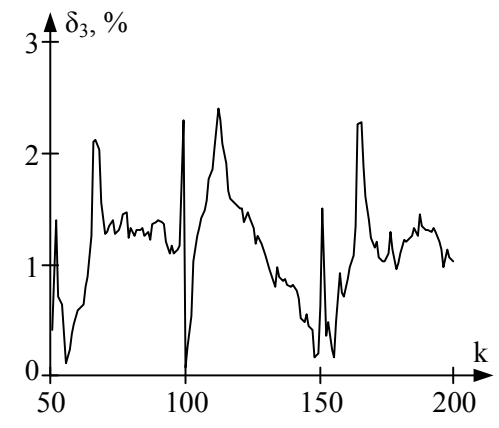

B)

Рисунок 4 - Похибки моделі для стресового стану 


\section{«Системні технології» 5 (130) 2020 «System technologies»}

На основі аналізу отриманих результатів розрахунків можна відмітити, що:

1.Значення всіх власних чисел (6) матриці $\hat{\mathbf{A}}_{f}$ за абсолютною величиною менше одиниці. Це свідчить про стаціонарність процесу (2).

2. Для напруженого стану одне з власних значень (8) матриці $\hat{\mathbf{A}}_{f}$ становиться більш за одиницю, тобто стаціонарність процесу (2) порушується.

3. Оцінка коефіцієнту зовнішніх обурень при стресовому стані зменшується на $12 \%$ відносно тієї ж оцінки у фоновому стані $\left(\hat{b}_{f}>\hat{b}_{s}\right)$. Це можна пояснити як зменшення здатності сприйняття зовнішніх вхідних сигналів.

Висновки. Аналіз результатів виказав, що використання методу найменших квадратів дозволяє отримувати оцінки параметрів моделі динамічного об'єкту на основі обробки даних від підсистеми моніторингу, які можна застосовувати для діагностики стану в реальному часі. Це відкриває шляхи для своєчасного виявлення перевантажень і запобігання екстремальних умов функціонування. Доцільно здійснити дослідження закономірностей зміни параметрів моделей для різного типу людей та при різному ступені напруженості.

\section{ЛІТЕРАТУРА / ЛИТЕРАТУРА}

1. Носенко Э.Л. Теоретико-психологические основы компьютерной диагностики эмоциональной устойчивости человека. / Э.Л. Носенко, И.Ф. Аршава. - Днепропетровск: Изд-во ДГУ, 2006. - 236 с.

2. Киричков В.Н. Автоматика и управление в технических системах. В 11ти кн. Кн.2. Идентификация объектов систем управления технологическими процессами / В.Н. Киричков; под ред. А.А. Краснопрошиной. - К.: Выща шк. 1990. - 263 с.

3. Ким Д.П. Теория автоматического управления. Т.2. Многомерные, нелинейные, оптимальные и адаптивные системы: Учеб. пособие. - М.: ФИЗМАТЛИТ, 2004. - 464c.

4. Rudakova H. Using Recurrent Procedures in Adaptive control System for Identify the Model Parameters of the Moving Vessel on the Cross Slipway / $\mathrm{H}$. Rudakova, O. Polyvoda, A. Omelchuk //Data 2018, 3(4), 60. 
«Системні технології» 5 (130) 2020 «System technologies»

5. Домбровский В.В. Эконометрика: Учебник для вузов / В.В. Домбровский. - М.: Новый учебник, 2004. - 342с.

\section{REFERENCES}

1. E.L. Nosenko, I.F. Arshava, Theoretical and psychological foundations of computer diagnostics of human emotional stability. Dnepropetrovsk: Publishing House of the DSU, 2006, 236 p. (in Russian)

2. V.N. Kirichkov, Object identification process control systems. Kiev: Vyshcha shkola, 1990, 263p. (in Russian)

3. D.P. Kim, Automatic control. Theory Nonlinear and Multivariable System. Seol: Harnol, 2000, 558 p.

4. Rudakova H. Using Recurrent Procedures in Adaptive control System for Identify the Model Parameters of the Moving Vessel on the Cross Slipway / H. Rudakova, O. Polyvoda, A. Omelchuk //Data 2018, 3(4), 60.

5. V.V. Dombrovsky, Econometrics: Textbook for high schools. M.: New textbook, 2004, $342 \mathrm{p}$.

Received 02.03.2020. Accepted 06.03.2020.

Идентификация напряженного состояния человека-оператора

В данной статье авторами проведено исследование биофизических параметров, которые изменяются во время выполнения операций разного характера и могут измеряться с помощью датчиков. Обоснована возможность определения уровня напряженности состояния человека и оценивания сложности оперативной ситуации на основе анализа данных, которые фиксируются по результатам измерений. Доказано, что использование метода наименьших квадратов позволяет получать оценки параметров модели динамического объекта, на основе которой можно адекватно идентифицировать состояние человека-оператора.

\section{Identification of the human operator stress conditions}

Performing their professional duties, people often find themselves in a situation where you need to make a decision. In this case, the stress conditions of the operator tends to increase when managing any process in real time, especially in lack of time. Constant monitoring of the level of the human stress conditions allows to identify in advance the pre-stress and stress conditions and to take certain measures to stabilize the situation. Human condition can be determined by biophysical parameters that change during different operations and can be measured using sensors. Based on the analysis of data recorded on the results of measurements, it is possible to identify the level of the human stress condition and to assess the complexity of the operational situation. To identify model parameters in real time, it is advisable to use repetitive procedures that allow to obtain an estimate of model parameters when new measurements are received. The purpose of the article is to evaluate the parameters of the mathematical model based on the analysis of the recorded biophysical parameters of the human organism, and to evaluate the possibility of their use for the identification of stress conditions. The model parameter estimates are calculated for three dynamic human-specific processes: cardiogram, rheogram, pneumogram. Observation data were obtained for two cases: in a calm (background) conditions of a human and in a stressful (tense) conditions of the same person. The analysis of the results 
«Системні технологіï» 5 (130) 2020 «System technologies»

showed that the use of the least squares method allows to obtain estimates of the parameters of the dynamic object model based on the processing data from the monitoring subsystem, which can be used for real-time diagnostics. This opens the way to detect overloads in a timely manner and prevent extreme operating conditions. It is advisable to study the regularity of change of model parameters for different types of people and at different level of stress conditions.

Колосов Игорь Владимирович - директор крюингового департамента ООО «Марлоу Навигейшн Украина», (аспирант кафедры эксплуатации судового электрооборудования и средств автоматики Херсонской государственной морской академии).

Поливода Оксана Валериевна - доцент кафедры автоматизации, робототехники и мехатроники Херсонского национального технического университета.

Рудакова Анна Владимировна - профессор кафедры автоматизации, робототехники и мехатроники Херсонского национального технического университета.

Колосов Ігор Володимирович - директор крюінгового департаменту ТОВ «Марлоу Навігейшн Україна», (аспірант кафедри експлуатації суднового електрообладнання і засобів автоматики Херсонської державної морської академії).

Поливода Оксана Валеріївна - доцент кафедри автоматизації, робототехніки і мехатроніки Херсонського національного технічного університету.

Рудакова Ганна Володимирівна - професор кафедри автоматизації, робототехніки і мехатроніки Херсонського національного технічного університету.

Kolosov Igor - Director of Crewing Department, Marlow Navigation Ukraine (Postgraduate Student of the Ship Electrical Equipment and Automatic Devices Operation Department, Kherson State Marine Academy).

Polyvoda Oksana - Assistant Professor of the Automation, Robotics and Mechatronics Department, Kherson National Technical University.

Rudakova Hanna - Professor of the Automation, Robotics and Mechatronics Department, Kherson National Technical University. 